\title{
OKOLJSKI UČINKI PROMETA IN TURIZMA V SLOVENIJI
}

\section{Dejan Cigale, Barbara Lampič, Irena Mrak, Matej} Ogrin, Blaž Repe, Metka Špes, Katja Vintar Mally,

Katja Vrtačnik Garbas: Okoljski učinki prometa in turizma v Sloveniji. Zbirka GeograFF 5. Znanstvena založba Filozofske fakultete in Oddelek za geografijo, 205 str. Ljubljana 2009.

Knjiga Okoljski učinki prometa in turizma v Sloveniji prinaša prispevke osmih avtorjev geografov, ki se ukvarjajo s celovito problematiko neposrednih in posrednih vplivov na

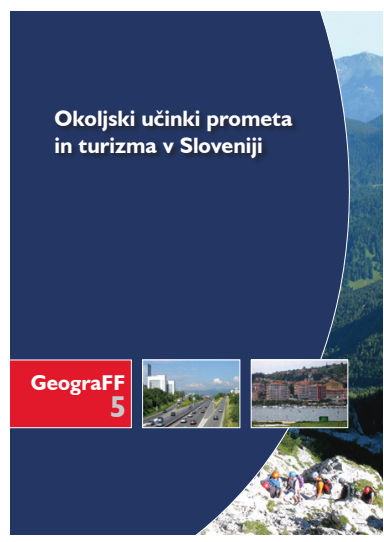
okolje dveh gospodarskih in razvojno izredno pomembnih dejavnosti v Sloveniji, prometa in turizma, ki pa sta po svojih temeljnih gospodarskih, geografskih in prostorskih potezah razmeroma zelo različni. Le-to seveda pomembneje vpliva na prostorsko strukturo in funkcije obeh dejavnosti in z njimi povezane okoljske učinke. To dejstvo povzroča številnim raziskovalcem okoljskih učinkov omenjenih dejavnosti kar nekaj teoretsko-metodoloških zadreg, s katerimi se seveda soočajo tudi geografi pri preučevanju okoljskih učinkov človeka in človekovih dejavnosti. Že v prvem uvodnem prispevku, ki prikazuje promet in turizem v razmerju do pokrajinske občutljivosti Slovenije (M. Špes), je v celoti nakazana znanstvena in strokovna problematika geografske razsežnosti preučevanja okoljskih učinkov prometa in turizma znotraj koncepta sonaravnega razvoja. Promet je obravnavan v kontekstu analize trinajstih pokrajinskoekoloških tipov Slovenije, ki kaže, da so z vidika prometne obremenjenosti na udaru predvsem štirje tipi: medgorske kotline, širše rečne doline v visokogorju, hribovju in na krasu, ravnine in širše doline v gričevju notranjega dela Slovenije in širše doline in obalne ravnice v primorskem delu. Turizem pa je obravnavan v kontekstu ekosistemov (gorski, morski, kraški) in okoljske občutljivosti teh sistemov, ki lahko predstavljajo pomembno omejitev nadaljnjemu sonaravnemu razvoju.

$\mathrm{Na}$ področju prometa prikazuje razvoj in vloga cestnega prometa (B. Lampič, M. Ogrin) prometno omrežje in prometne tokove, stopnjo motorizacije, obseg potniškega in blagovnega prometa ter s tega vidika stanje na področju prometne obremenjenosti. Nadaljuje se v prispevek o tipizaciji prostora glede na prometno obremenjenost cest, ki prikazuje značilnosti opredeljenih tipov prometnih območij v Sloveniji na podlagi izbranih kazalcev (gostota poselitve, povprečne obremenitve, navadna linearna gostota cest in združen kazalnik obremenitve), in sicer v mestna območja z velikimi prometnimi zgostitvami in obremenitvami, nadpovprečno prometno obremenjene ceste - velike linijske obremenitve, prometno zmerno obremenjena območja in prometno neobremenjena območja.

Sledi prispevek o prometnem obremenjevanju ozračja (M. Ogrin), ki se nanaša na posamezne vidike prometnega onesnaževanja ter vprašanja vpliva prometnega onesnaževanja ozračja na kakovost zraka. Ravno zaradi tega so bile opravljene s strani geografov nekatere meritve in analize kakovosti zraka v treh različnih tipih prostora ob cestah v Sloveniji: cestnih koridorjih, odprtih prostorih ob cestah in tako imenovanih ozadjih. Zadnji prispevek 
s področja prometa je namenjen prikazu zaznavanja prometa kot pritiska na okolje v izbranih območjih Slovenije (K. Vintar Mally), in sicer z vidika zaznavanja okoljskih problemov v bivalnem okolju in znotraj tega zaznavanju vplivov cestnega prometa na podlagi ocene vplivov cestnega prometa in odzive prebivalstva na zaznane probleme v izbranih naseljih Koprskega Primorja in Prekmurja med leti 2005 in 2006.

Uvodno besedilo na področju okoljskih učinkov turizma v Sloveniji je namenjeno prikazu turizma in rekreacije kot dejavnika okoljskih obremenitev (D. Cigale) na podlagi preučevanja okoljskih učinkov turizma in rekreacije ter strukturiranja teh vplivov na posamezne elemente okolja (voda, zrak, relief in prsti, rastlinstvo in živalstvo) in medsebojno prepletenost različnih učinkov turizma in rekreacije. Ti učinki so v poskusu skupne ocene obremenitev zaradi turizma in rekreacije po občinah v slovenskem alpskem svetu nakazani zgolj z načelnega vidika. $\mathrm{V}$ prispevku je obseg literature in virov nenavadno obsežen. Isti avtor obravnava v vplivih nastanitvenih objektov na okolje različne vidike okoljskih vplivov teh objektov ter podaja stanje na področju nastanitvenih zmogljivosti v Sloveniji na ravni občin in na tej podlagi izpostavlja nekatere problematične vidike v zvezi s počitniškimi bivališči, ki se nanašajo na veliko prostorsko razpršenost, preveliko zgostitev na posameznih območjih, težnjo po zgoščevanju počitniških bivališč na najbolj privlačnih območjih, naraščanju počitniških bivališč in problematiko okoljskih vplivov. Kot poseben, a žal edini okoljski problem, poleg porabe elektrike in vode, izpostavlja odpadke iz nastanitvenih objektov.

K. Vrtačnik Garbas predstavlja alpsko smučanje kot vir okoljskih obremenitev, ki se kažejo v negativnih učinkih alpskega smučanja na okolje in so povezani z učinki zaradi gradbenih posegov in obratovanja smučišč, $v$ drugem delu pa podrobneje analizira izbrana smučišča $\mathrm{v}$ Sloveniji z vidika posameznih izbranih kazalcev (nadmorske višine, zmogljivosti, površine, dolžine, število naprav, število smučarjev, vodne vire in število topov za zasneževanje). Na tej podlagi je podana ocena o zmerni intenzivnosti okoljskih vplivov smučišč v Sloveniji.

I. Mrak podaja značilnosti in okoljske vplive gorništva, ki se kažejo tudi v obliki negativnih okoljskih vplivov, med katerimi posebej izpostavlja gradnjo infrastrukture, povečanje količin nerazgradljivih odpadkov, neposredne vplive na naravno okolje, vplive na prehranjevalne in razmnoževalne navade živali v naravnem okolju in vplive na občutljive ekosisteme.

Naravna ogroženost Slovenije z vidika erozije pohodniških poti (B. Repe, I. Mrak) podaja na podlagi dejavnikov, ki vplivajo na verjetnost pojava vodne in/ali vetrne erozije prsti členitev Slovenije na posamezne kategorije potencialne naravne ogroženosti z vidika erozije pohodniških poti (majhno, srednjo, veliko in zelo veliko ogroženost) ter stopnjo ogroženosti slovenskih pokrajin zaradi vodne erozije prsti. V prispevku ni v celoti pojasnjeno razmerje med območji potencialne ogroženosti in kazalci o intenzivnosti pohodništva (gostota planinskih poti).

Zadnji prispevek z naslovom Zaznavanje turizma in rekreacije kot pritiska na okolje v slovenskih turističnih krajih (D. Cigale) podrobneje prikazuje rezultate obsežne ankete o okoljskih vplivih turizma v slovenskih turističnih krajih, in sicer v obliki mnenj anketirancev o vplivih turizma in rekreacije na okolje v izbranih turističnih območjih. Na tej podlagi je podana ocena vpliva turizma in rekreacije na turistične kraje v Alpski Sloveniji, na območju Posotelja in na območju Koprskega Primorja. 
Knjiga z naslovom Okoljski učinki prometa in turizma v Sloveniji nedvomno izraža vsebinsko in metodološko bogastvo preučevanja okoljskih učinkov tako na področju prometa kot turizma in prinaša nekatera nova dejstva in spoznanja. Pestrost obravnave posameznih vidikov in elementov okoljske problematike na področju prometa in turizma se kaže predvsem $\mathrm{v}$ dobro strukturiranem geografskem analitičnem značaju prispevkov, katerih medsebojna vsebinska povezanost pa je žal marsikje odsotna in ni ustrezno obrazložena in utemeljena, kar vedno ne omogoča neposrednega jasnega in celovitega ter nedvoumnega razumevanja najpomembnejših geografskih in prostorskih razsežnosti okoljskih učinkov prometa in turizma $\mathrm{v}$ Sloveniji.

Andrej Černe 